\title{
Is There an Association Between Hepatitis B and Atherosclerosis?
}

\author{
Kronik Hepatit B Enfeksiyonu Ateroskleroza Yol Açar Mı?
}

\author{
๑ Zuhal Çalışkan, • Özge Telci Caklıı
}

Kocaeli State Hospital, Clinic of Internal Medicine, Kocaeli, Turkey

\begin{abstract}
Objectives: Although hepatitis B infection can cause chronic disease, its association with atherosclerosis is a matter of debate. Retinopathy is an early marker for microvascular abnormalities of retinal circulation and some reports state that it can predict cardiovascular events. In this study, we aimed to evaluate early atherosclerosis in patients with chronic hepatitis $\mathrm{B}(\mathrm{CHB})$ using retrobulbar flow velocities.

Materials and Methods: The study included 56 patients with $\mathrm{CHB}$ and 45 controls. Patients with hepatitis B who attended Ümraniye Training and Research Hospital Gastroenterology outpatient clinics were screened. Pulsed Doppler documentation of flow velocity was obtained from ophthalmic artery, posterior ciliary artery and central retinal artery (CRA). The resistive index for each artery was calculated using the following formula: peak systolic velocity (PSV)-end-diastolic velocity (EDV)/PSV.

Results: The mean age of the patients and controls was $46.18 \pm 13.7$ and $45.89 \pm 8.6$ years, respectively. There were 29 males and 27 females in CHB group and 16 males and 29 females in control group. The patients with CHB had statistically lower PS flow and ED flow of CRA compared to controls [( $10.9 \pm 3.1$ vs $12.1 \pm 3.09, p=0.047)$ and $(2,8 \pm 1,1$ vs $3,2 \pm 1,1, p=0.027)$, respectively].

Conclusion: Our findings show no increase in retrobulbar flow velocities of patients with $\mathrm{CHB}$ compared to controls.

Keywords: Hepatitis B, atherosclerosis, retrobulbar blood flow velocity
\end{abstract}

\section{$0 ̈ Z$}

Amaç: Hepatit B enfeksiyonu kronik karaciğer hastalığına neden olmaktadır. Buna rağmen kronik hepatit B'ye (KHB) bağı enflamasyona ikincil ateroskleroz ile ilişsisi kesin değildir. Retinal arterlerin dolaşımının erken aterosklerozu öngörebilme yeteneği olduğuna dair literatürde yayınlar mevcuttur.

Gereç ve Yöntemler: Bu çalışmamızda KHB hastalarında retrobulbar akım hızları ile erken aterosklerozu değerlendirmeyi amaçladık. Çalışmaya 56 KHB hastası ve 45 sağlıklı kontrol katıldı. 2019 yılı içerisinde (kör değerlendirme için belirtilmedi) Ümraniye Eğitim ve Araştırma Hastanesi, Gastroenteroloji Kliniği'nde takip edilen Hepatit B tanısı olan karaciğer biyopsisi pozitif hastalar tarandı. Pulsed Doppler yardımı ile oftalmik arter, posterior silier arter ve santral retinal arter (SRA)gözlendi. Her arter için direnç indeksi formüle göre hesaplandı: Tepe sistolik akım (TSA)-diyastol sonu akım (DSA)/TSA. Bulgular: Hastaların ortalama yaşı $46.18 \pm 13.7$ iken kontrol katılımcıların 45.89 \pm 8.6 idi. Yirmi dokuz erkek ve 27 kadın hasta KHB grubunda iken, bu oran kontrol grubunda sırasıyla 16'ya 29 idi. KHB hastalarının kontrol grubuna göre daha düşük TSA ve DSA akımlarının olduğu gözlendi $[(10,9 \pm 3,1$ vs $12,1 \pm 3,09, p=0,047)$ ve $(2,8 \pm 1,1$ vs $3,2 \pm 1,1, p=0,02)$, sirasiyla].

Sonuç: Calıșmamızda KHB hastalarının retrobulbar akım hızlarında kontrol grubuyla karşılaştırıldığında artış gözlenmemiştir.

Anahtar Kelimeler: Hepatit B, ateroskleroz, retrobulbar kan akımı

Çalışkan Z, Telci Cakııı Ö. Is There an Association Between Hepatitis B and Atherosclerosis? Viral Hepat J. 2019;25:35-39.

\section{Introduction}

Hepatitis B virus infection is a common disease in the world. The World Health Organization estimated that 257 million people were living with hepatitis B in 2017 (1). Chronic hepatitis B
(CHB) infection can cause extrahepatic manifestations such as polyarthritis nodosa, glomerulonephritis and skin disorders (2).

Atherosclerosis is now considered a systemic disease related to chronic inflammation (3). In patients with chronic inflammatory diseases, such as rheumatoid arthritis, seronegative polyarthritis

Address for Correspondence: Özge Telci Caklılı MD, Kocaeli State Hospital, Clinic of Internal Medicine, Kocaeli, Turkey 
or Behçet's disease, atherosclerosis is more common than in the general population $(4,5,6)$. Although $\mathrm{CHB}$ infection can cause chronic disease, its association with atherosclerosis is controversial. In their study, Völzke et al. (7) reported that there was no association between hepatitis $\mathrm{B}$ and $\mathrm{C}$ virus infection and atherosclerosis risk, however, Targher et al. (8) have reported higher carotid intima media thickness (cIMT) values in patients with $\mathrm{CHB}$ compared to controls.

Most of the studies used cIMT to evaluate atherosclerosis. Retrobulbar blood flow velocity measurement is a relatively new method to assess early atherosclerosis (9). Retinopathy is an early marker for microvascular abnormalities of retinal circulation and some reports stated that it could predict cardiovascular events (10). Current literature shows increased resistance index in patients with atherosclerosis compared to controls (11). To assess retinal circulation, retrobulbar velocities of central retinal artery (CRA), posterior ciliary artery (PCA) and ophthalmic artery are measured and their resistance index is calculated. In this study, we aimed to evaluate early atherosclerosis in patients with $\mathrm{CHB}$ using both retrobulbar flow velocities and cIMT.

\section{Materials and Methods}

\section{Study Population}

The study included 56 patients with $\mathrm{CHB}$ and 45 controls. Patients with hepatitis B who were followed at Ümraniye Training and Research Hospital Gastroenterology outpatient clinics between on 2019 were screened. Ethics Committee approval was obtained from Istanbul Medeniyet University Ethics Committee (approval number: 2019/0239). All the patients were hepatitis B surface antigen (HbsAg)-positive, none of the patients were positive for anti-HBs, and all patients had liver biopsyproven $\mathrm{CHB}$. Both patients and controls were inquired regarding their coronary artery disease history and those with a history of coronary artery disease were excluded. Patients with diabetes mellitus, chronic kidney disease and any other systemic disease and pregnant patients were also excluded. Informed consent was obtained from all the patients at every step of the study. The study was conducted in accordance the principles of the Helsinki Declaration.

\section{Biochemical Assessment}

Venous blood samples were obtained from each study participant after an overnight fast for biochemical analysis. The spectrophotometric method (Aeroset Automated Analyzer, Abbott Laboratories, Abbott, IL) was used for blood glucose measurement. Albumin, urea, and creatinine levels were determined. Enzymatic methods were used to measure triglyceride levels and total cholesterol as well as high-density lipoprotein (HDL) and lowdensity lipoprotein (LDL).

\section{Echocardiographic Examination}

A GE Vivid 7 (Horten, Norway) echocardiography unit was used for echocardiographic examination. Echocardiographic evaluations were performed in parasternal long-axis view, using two-dimensional, M-mode, standard- and pulsed-tissue Doppler. Measurements were performed with M-mode images. One blinded investigator completed the echocardiography, while a pair of blinded cardiologists performed the analysis of the echocardiographic recordings.

\section{Carotid Intima Media Thickness Measurement}

A GE Logic 5 ultrasound scanner (General Electric Medical Systems, Wallingford, CT) was employed in measuring CIMT. A trained radiologist, who was blinded to patient data, performed the sonic evaluations. The head was in midline position and tilted a little bit upward during the left common carotid artery evaluations. A $7.5 \mathrm{MHz}$ linear probe was positioned parallel to both the near and the far wall of the carotid artery and lumen diameter was amplified as much as possible along the longitudinal plane (12). cIMT measurements were taken at approximately one centimeter proximal to the common carotid artery bifurcation. The distance between the media-adventitia interface and the lumen-intima interface served as the definition of cIMT (12).

\section{Retrobulbar Blood Flow Velocities and Resistivity Index Measurement}

Examinations were performed on the right eye. Color Doppler ultrasonography examinations were performed by an operator who received training with Toshiba Aplio XU Ultrasound device (Toshiba America Medical Systems, Inc., Tustin, CA) using a 12.5 $\mathrm{MHz}$ linear array probe. A uniform protocol governed ultrasound technique and subject positioning as well as arterial vessel location (13). The subjects were positioned in the supine position with their left, unexamined eye trained on a point directly above their head. Examinations were performed with the operator behind the subject and the probe and gel lightly applied to the eyelids. Care was taken to optimize the quality of the ultrasound imaging while the settings of the ultrasound device was kept constant throughout the operation. The ophthalmic artery was located where it ran on the optic nerves' medial side using the mode for color imaging, which was similarly employed concerning the PCA and CRA. Pulsed Doppler documentation of flow velocity was obtained with a $1.5 \mathrm{~mm}$ gate size and the angle of the Doppler under 60, as previously identified (13). The resistive index for each artery was calculated using the following formula: peak systolic velocity (PSV)end-diastolic velocity (EDV)/PSV. The same operator performed the measurements again to calculate intraobserver of coefficient of variation (CV). CV was subsequently calculated using the results of all 10 measurements with the following formula: 100 mean \pm standard deviation. CVs were computed for PSV, EDV, as well as resistivity index (RI).

\section{Statistical Analysis}

All analysis was performed with SPSS 9.0 (SPSS for Windows 9.0, Chicago, IL). Variables were expressed as mean \pm standard deviation. To test normality of variables, Shapiro-Wilk and Kolmogorov-Smirnov tests were used. The Student's t-test or Mann-Whitney $U$ test was used for comparison of two groups. A $p$ value below 0.05 was considered statistically significant.

\section{Results}

\section{Study Population}

The mean age of the patients and controls was $46.18 \pm 13.7$ and $45.89 \pm 8.6$ years, respectively. There were 29 males and 27 
females in CHB group and 16 males and 29 females in control group. Table 1 shows the demographic characteristics of both groups. There was a statistically significant difference in bilirubin, C-reactive protein, HDL cholesterol, LDL cholesterol, aspartate aminotransferase (AST) and albumin levels (Table 1).

\section{Echocardiographic Examination}

Interventricular septum, posterior wall thickness, left ventricleED diameter, left ventricle-end-systolic diameter and left ventricular ejection fraction were similar in two subgroups (Table 2).

\section{CIMT Measurement}

There was no difference in cIMT values between the patients and controls $(0.53 \pm 0.17$ vs $0.51 \pm 0.14 ; p=0.808)$.

\section{Retrobulbar Blood Flow Velocities and Resistivity Index Measurement}

There was a significant difference in PS flow and ED flow of CRA between the groups. Patients with CHB had lower PS

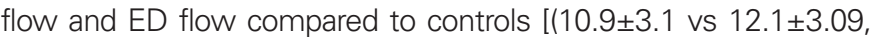

$(p=0.047)$ and $(2.8 \pm 1.1$ vs $3.2 \pm 1.1,(p=0.027)$, respectively]. There was no difference in resistivity index of CRA. The PSV, EDV, RI of PCA and ophthalmic artery did not differ between the groups (Table 3).

\section{Discussion}

This study aimed to investigate the difference in retrobulbar blood flow velocity between patients with $\mathrm{CHB}$ and healthy controls. To our knowledge, this is the first study to test this hypothesis. Our findings show no increase in blood flow velocities and in resistance indices.

Although $\mathrm{CHB}$ can become a chronic disease, association between $\mathrm{CHB}$ and atherosclerosis is not clear in the literature. Observational studies revealed conflicting results. Völzke et al. (7) investigated the association of $\mathrm{CHB}$ with myocardial infarction, cIMT and stroke. They reported no independent association between hepatitis B infection and atherosclerotic endpoints. Complicating the subject more, a study has proposed a decrease in ischemic stroke

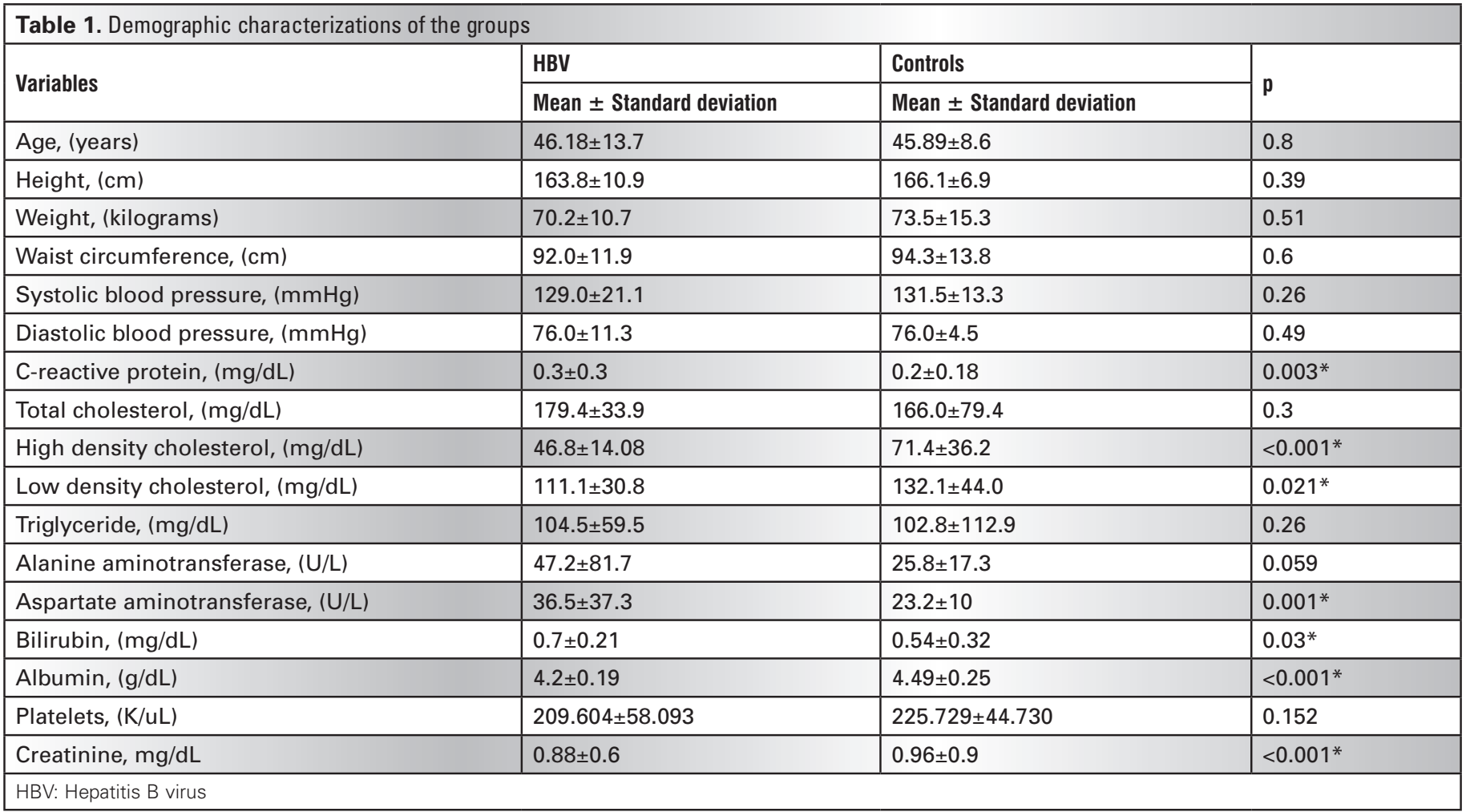

\begin{tabular}{|c|c|c|c|}
\hline \multirow{2}{*}{ Variables } & HBV & Controls & \multirow{2}{*}{$\mathrm{p}$} \\
\hline & Mean \pm Standard deviation & Mean \pm Standard deviation & \\
\hline $\mathrm{LA},(\mathrm{mm})$ & $3.05 \pm 0.44$ & $3.5 \pm 0.4$ & $0.006^{*}$ \\
\hline LV systolic diameter, (mm) & $4.6 \pm 0.46$ & $4.7 \pm 0.42$ & 0.6 \\
\hline LV diastolic diameter, $(\mathrm{mm})$ & $2.8 \pm 0.32$ & $3.02 \pm 0.39$ & 0.24 \\
\hline Septum, (mm) & $0.9 \pm 0.14$ & $0.87 \pm 0.13$ & 0.5 \\
\hline Posterior Wall, (mm) & $0.84 \pm 0.14$ & $0.78 \pm 0.09$ & 0.053 \\
\hline $\mathrm{EF},(\%)$ & $66 \pm 4.35$ & $65.2 \pm 4.3$ & 0.8 \\
\hline
\end{tabular}




\begin{tabular}{|l|l|l|l|}
\hline Table 3. Retrobulbar blood flow velocities & Controls & \multirow{2}{*}{$\mathbf{p}$} \\
\hline \multirow{2}{*}{ Variables } & HBV & Mean \pm Standard deviation & \\
\cline { 2 - 4 } & Mean \pm Standard deviation & $12.1 \pm 3.09$ & $0.047^{*}$ \\
\hline CRA PSV (cm/s) & $10.9 \pm 3.1$ & $3.2 \pm 1.1$ & $0.027^{*}$ \\
\hline CRA EDV (cm/s) & $2.8 \pm 1.1$ & $0.7 \pm 0.06$ & 0.7 \\
\hline CRA RI & $0.7 \pm 0.007$ & $11.7 \pm 3.4$ & 0.9 \\
\hline PCA PSV (cm/s) & $11.7 \pm 3.2$ & $3.9 \pm 1.6$ & 0.6 \\
\hline PCA EDV (cm/s) & $3.7 \pm 1.2$ & $0.66 \pm 0.07$ & 0.3 \\
\hline PCA RI & $0.6 \pm 0.06$ & $38.5 \pm 9.7$ & 0.4 \\
\hline OA PSV (cm/s) & $37.2 \pm 9.1$ & $10.9 \pm 4.05$ & 0.28 \\
\hline OA EDV (cm/s) & $10.1 \pm 3.6$ & $0.69 \pm 0.11$ & 0.18 \\
\hline OA RI & $0.7 \pm 0.07$ & $0.51 \pm 0.14$ & 0.808 \\
\hline cIMT (cm) & $0.53 \pm 0.17$ & \\
\hline $\begin{array}{l}\text { HBV: Hepatitis B virus, CRA: Central retinal artery, PSV: Peak systolic velocity, EDV: -end diastolic velocity, RI: Resistivity index, PCA: Posterior ciliary artery, OA: } \\
\text { Ophthalmic artery, clMT: Carotid intermedial thickness test }\end{array}$ \\
\hline
\end{tabular}

rates in patients with $\mathrm{CHB}$ (14). The authors have associated this decrease with lower age of $\mathrm{CHB}$ patients compared to controls. Another study has suggested a protective effect of $\mathrm{CHB}$ against atherosclerosis (15). In our study, age- and sex-matched controls were included, therefore, no age-related bias was present.

A meta-analysis has reported an increase in atherosclerosisassociated disease morbidity in patients exposed to HBV but this increase was not statistically significant (16). Targher et al. (8) showed increased cIMT in patients with $\mathrm{CHB}$ compared to controls $(0.9 \pm 0.1 \mathrm{vs} 0.8 \pm 0.1)$ and the difference was statistically significant. In our study, cIMT in both patients and controls did not exceed $0.6 \mathrm{~mm}$. The mean age of the patients was almost the same in both studies, therefore, this difference in cIMT may be attributed to ethnic differences.

Our study is the first in the literature to investigate retrobulbar blood flow velocities in patients with $\mathrm{CHB}$ and lack of a difference between patients and controls is consistent with some of the literature reporting no relationship between $\mathrm{CHB}$ and atherosclerosis. Although not definitive, surrogate markers of atherosclerosis are convenient tools to identify patients at risk. In this study, we used two surrogate markers to investigate the relationship and neither of them showed a difference. However, Ishizaka et al. (17) reported increased plaque formation in HBsA carriers. They have also used a surrogate marker-carotid ultrasound and they found HBsAg positivity to be a risk factor for carotid atherosclerosis that was independent from other confounding risk factors.

There were significant differences in biochemical markers showing liver capacity such as bilirubin and albumin, therefore, we can say that our study cohort had sufficient number of patients with liver associated-disease to test the hypothesis. Also, no difference was observed between patients and controls with regard to height, weight and waist circumference.

\section{Study Limitations}

This study has some limitations that should be noted. Our study cohort was relatively small. With a larger sample size, findings may differ. Also, this is a cross-sectional case-control study. A study with follow-up of these patients may obtain more information regarding their metabolic status and atherosclerotic events.

\section{Conclusion}

In this first study to test retrobulbar blood flow velocity in patients with $\mathrm{CHB}$, we found no increase in patients compared to controls. Our findings are consistent with some of the literature reporting no association between $\mathrm{CHB}$ and atherosclerosis, however, further studies are needed to reach a clear conclusion.

\section{Ethics}

Ethics Committee Approval: Ethics Committee approval was obtained from Istanbul Medeniyet University Ethics Committee (approval number: 2019/0239).

Informed Consent: Informed consent was obtained from each patient.

Peer-review: External and internal peer-reviewed

\section{Authorship Contributions}

Surgical and Medical Practices: Z.Ç., Concept: Z.Ç., Design: Z.Ç., Data Collection or Processing: Z.C.., Ö.T.C., Analysis or Interpretation: Ö.T.C., Literature Search: Z.Ç., Ö.T.C., Writing: Ö.T.C.

Conflict of Interest: Authors declare no conflict of interest.

Financial Disclosure: There was no aid and sponsor for this study.

\section{References}

1. World Health Organization. Global hepatitis report 2017. World Health Organization. 2017.

2. Han SH. Extrahepatic manifestations of chronic hepatitis B. Clin Liver Dis. 2004;8:403-418

3. Ross R. Atherosclerosis-an inflammatory disease. N Engl J Med. 1999;340:115-126

4. Libby P. Role of inflammation in atherosclerosis associated with rheumatoid arthritis. Am J Med. 2008;121(10 Suppl 1):21-31.

5. Sari I, Okan T, Akar S, Cece H, Altay C, Secil M, Akkoc $\mathrm{N}$. Impaired endothelial function in patients with ankylosing spondylitis. Rheumatology (Oxford). 2006;45:283-286. 
6. Seyahi E, Ugurlu S, Cumali R, Balci H, Ozdemir O, Melikoglu M, Yazici $\mathrm{H}$. Atherosclerosis in Behçet's syndrome. Semin Arthritis Rheum. 2008;38:1-12.

7. VölzkeH,Schwahn C, WolffB, MentelR, Robinson DM, Kleine V, John $\mathrm{U}$. Hepatitis $\mathrm{B}$ and $\mathrm{C}$ virus infection and the risk of atherosclerosis in a general population. Atherosclerosis. 2004;174:99-103.

8. Targher G, Bertolini L, Padovani R, Rodella S, Arcaro G, Day C. Differences and similarities in early atherosclerosis between patients with non-alcoholic steatohepatitis and chronic hepatitis $B$ and C. J Hepatol. 2007;46:1126-1132.

9. Keles N, Caliskan M, Aksu FU, Keles NN, Karagoz V, Tekin AS, Bakan A. Retrobulbar blood flow and carotid intima-media thickness alteration may relate to subclinic atherosclerosis in patients with chronic inflammatory diseases. Renal Fail. 2015;37:1164-1170.

10. Cheung N, Wang JJ, Klein R, Couper DJ, Sharrett AR, Wong TY. Diabetic retinopathy and the risk of coronary heart disease: the Atherosclerosis risk in communities study. Diabetes Care. 2007;30:1742-1746.

11. Keles N, Caliskan M, Keles NN, Aksu F, Aung SM. Assesment of microcirculatory function with retrobulbar blood flow velocity measurement predicting cardiovascular events. Inflammation and Cell Signaling. 2016:3.
12. Persson J, Formgren J, Israelsson B, Berglund G. Ultrasounddetermined intima-media thickness and atherosclerosis. Direct and indirect validation. Arterioscler Thromb. 1994;14:261-264.

13. Tranquart F, Bergès $O$, Koskas P, Arsene $S$, Rossazza C, Pisella PJ, Pourcelot L. Color Doppler imaging of orbital vessels: personal experience and literature review. J Clin Ultrasound. 2003;31:258273.

14. Tseng $\mathrm{CH}$, Muo $\mathrm{CH}$, Hsu $\mathrm{CY}, \mathrm{Kao} \mathrm{CH}$. Association of hepatitis $B$ virus infection with decreased ischemic stroke. Acta Neurol Scand. 2016;134:339-345

15. Bilora F, Rinaldi R, Boccioletti V, Petrobelli F, Girolami A. Chronic viral hepatitis: a prospective factor against atherosclerosis. A study with echo-color Doppler of the carotid and femoral arteries and the abdominal aorta. Gastroenterol Clin Biol. 2002;26:10011004.

16. Li CG, Liao SJ, Que JL, Liu KJ, Wang HY, Yu J. The relationship between exposure to hepatitis $B$ virus and increased atherosclerosis-associated morbidity-a meta-analysis. Kardiol Pol. 2018;76:119-124

17. Ishizaka N, Ishizaka Y, Takahashi E, Toda Ei El, Hashimoto H, Ohno M, Yamakado M. Increased prevalence of carotid atherosclerosis in hepatitis B virus carriers. Circulation. 2002;105:1028-1030. 